Culture, Personality and Education

МәАәният, шәхес һәм мәгарифр

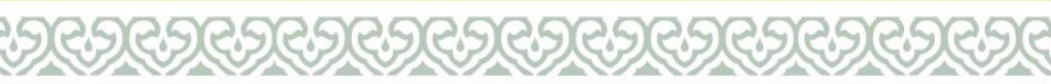

Культура, Аичность и образование

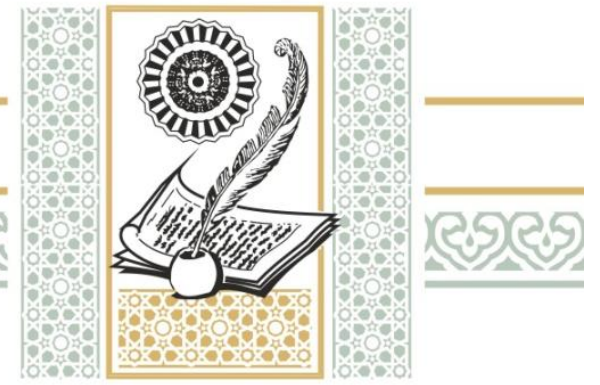

DOI: $10.26907 / 2311-2042-2020-14-1-103-117$

\title{
ON THE GROUP OF THE CRIMEAN TATARS' EMBROIDERY IN THE NATIONAL MUSEUM OF THE REPUBLIC OF TATARSTAN
}

\author{
Liliya Ilevna Sattarova, \\ National Museum of the Republic of Tatarstan, \\ 2 Kremlevskaya Str., Kazan, 420111, Russian Federation, \\ liliya.sattarova@hotmail.com.
}

\begin{abstract}
For the first time the article presents a group of the Crimean Tatars' embroideries, which came to the museum collection in 1936 and 1997. The study traces the history of individual artifacts and their attribution, as well as a change in the purpose of using these things, which occurred in connection with the changes in the surrounding environment. The tradition of the Crimean Tatars' art of gold embroidery is shown in the complex of its technical and stylistic characteristics such as the main motifs and the most common compositional patterns, embroidery techniques, traditional base materials and special embroidery threads. The article draws analogies with a wide range of exhibits from the collections of Russian museums. Most items have been described for the first time.
\end{abstract}

Key words: Crimean Tatars, gold embroidery, embroidery techniques, National Museum of the Republic of Tatarstan, collections.

The Tatar seamstresses' art of gold embroidery, which became famous during the mass production of ichigs and qalyapushs in Kazan in the second half of $19^{\text {th }}$ century and the beginning of $20^{\text {th }}$, is very well represented in various museum collections of the Tatarstan Republic. The decorations on the traditional female headgear qalfaq, the male tubetey and qalyapush, and velvet women's shoes represent the range of the established ornaments, materials, and techniques of embroidery, as well as their most common combinations. The embroidery was done on dark velvet - blue, green, burgundy, brown - with metal threads of special quality, used to create three-dimensional seams us- ing the point couché technique. The stitching was done on a cardboard substrate, often using cotton wool wadding. A different order of stitches (satin stitch, featherstitch, checkerboard) as well as varying density, height, and pailettes promoted the diversity of the created decorative surfaces.

Another type of Tatar goldwork is the "Kazan towels", which were made with the chain stitch on white cloth, decorated with a gold rim and a fringe.

Thus, the range of goldwork items, made by Kazan Tatars, is limited [Gulova]. Golden embroidery is almost absent from traditional clothing; due to the lost tradition, the technique was not used in religious clothing, or in secular or religious decora- 
tions. In this context, the study of numerous artifacts, traditionally attributed to the collections of Tatar textile and embroidery, can yield interesting and surprising results. Thus, new approaches to the attribution of the "Qitap" cover from the collection of the Tatarstan State Museum of Fine Arts allowed us to argue in favour of its belonging to the Turkish-Ottoman embroideries of the second half of the $19^{\text {th }}$ century [Sattarova].

A number of embroideries in the ethnographic collection of the National Museum of the Republic of Tatarstan (hereafter - NM RT) stand out from the known examples of the Kazan goldwork due to their different techniques and styles. The items are different in terms of the base material (two are done on muslin, four on velvet, and two - on satin), as well as their purpose - they are male belts and sock straps, pouches, and pillow cases. We will examine these items in detail.

Two items made of white cloth, which are similar in terms of ornaments, materials, and technique, are decorated with a repeating pattern of stylised flowerpots, branches, leaves, and fruits. It has become accepted in literature to consider these artifacts as book (Quran) casings and attribute them to the $18^{\text {th }}-19^{\text {th }}$ centuries in the Kazan province region [Valeeva-Suleimanova, Shageeva, p. 166]; taking into account this attribution, these artifacts were shown at such exhibitions as "The Art of Islam" (2001, Kazan), "Treasures of the Museum of the Millennium of Kazan" (2005, Kazan), and "Decorative and Applied Art of Kazan Tatars: History and Present" (2009, Kazan, 2010, Ulyanovsk).

These embroideries have many similarities, both in composition and techniques used, with other artifacts from the collections of the Republican Crimean-Tatar Museum of Arts in Simferopol [Q1rımtatar, il. 58-60, 65, 69], the State Museum of Oriental Art (Moscow), the Russian Museum of Ethnography, the Saint-Petersburg Museum and other collections. The studies of the ethnography, art, and technology of the Crimean Tatars allow us to categorise these items as the groom's wedding belt, presented as a part of the wedding gift from the bride's side. The wedding gift consisted of nine items and was accordingly called "dokuz" ("dokuzlama").

The belts are distinguished by their diversity in the ensemble of the highland and coastal groups of Tatars. They reflected both the local traditions and the Turkish-Ottoman dress. The Ottoman tradition can be seen in the category of belts and the used materials. The qushaqs, worn over a dress, and the uchqurs, used to support trousers, had rich traditions of wearing, they were richly adorned, and could be a valuable gift and an important piece of a ceremonial dress. The collection of the Topkapi Museum Palace includes a $17^{\text {th }}$-century goldembroidered sash: a pattern of cypresses, arranged in a row of cypresses surrounded by branches with hyacinths, between which tulips are placed on a golden background with colored silk threads [Treasures, p. 161, cat. 82]. The male bridal belt of the Crimean Tatars was a part of the above said tradition - the groom did not use the belt after the wedding. It would seem the belt transformed to a ritualistic item with the evolving fashion, with the increase in the decorated area and gold embroidery. According to L. Roslavtseva, the wedding belt was called "qshaq": "towards the end of the $19^{\text {th }}$ century the belt was sewn together at the ends and put on over the head. Instead of being a regular item, it became a symbol of marriage" [Roslavtseva, p. 53].

The materials and techniques used in the embroidery of the wedding belt are of great interest. Traditionally, it was made from thin muslin, with its ends embroidered with coloured silk and metal threads. The samples from the NM RT, although similar in purpose, materials, composition, and motifs, differ in details of the stylised ornamental motifs and the embroidery technique.

Belt No.1 (KP-10664), made from a single piece of cloth $40 \mathrm{~cm}$ wide, retains the undecorated area in the centre. The decorated ends $(79 \mathrm{~cm}$ in width, $49 \mathrm{~cm}$ in height) of the belt are sewn together according to the tradition and are padded, likely later, with a cotton-based fabric.

Belt No. 2 (КП-24238) was acquired by the museum in 1997. According to M. Zavyalova, a keeper, the item traces its history back to the last owner's grandmother, a Crimean Tatar who was married in Kazan. In Crimea, the belt was used to decorate the house; in Kazan, the original owner's descendants used the belt for religious purposes the embroidered piece was used to cover the Quran. The center of the belt appears to have been cut in half, folded, and later covered with a denser cotton fabric; the dimensions of the decorated part are $65 \times 42 \mathrm{~cm}$.

The basis of the belt decorations is the "tree of life" motif. The image of a branching tree undoubtedly had a deep symbolic meaning, carrying a benevolent and well-wishing message, connected to both the life on earth, a happy marriage, fertility, as well as spiritual growth, the connection between 
generations, and the transfer of knowledge and experience.

The example, closest in composition to the items from the NM RT, is an artifact from the Simferopol Museum's collection [Q1rımtatar, p. 65]. Other belts feature a different "tree": a palm-like tree on the items from the State Museum of the Orient and the Simferopol Museum, and a tree with a vase at its base and identical six-petal flowers in the collection of the Simferopol Museum.

The embroidery on Belt No.1 is perhaps the best available example, due to the harmony of its composition, the balance of the ornament, and the density of the embroidery. The eight-petal rosette is repeated five times in its pattern - in the centre and at the corners. This motif is present in the ornament of wedding belts from the Stariy Krim region, specifically the ones recorded in the beginning of the $20^{\text {th }} \mathrm{c}$. by A. M. Petrova [Spasskaia, il.7 (387)]. It is the main motif in the women's gold embroidery from the second half of $19^{\text {th }} \mathrm{c}$., in the collection of the State Museum of the Orient (Moscow) from the Bakhchysaray region [Roslavtseva, color il. 6].

The composition is vertically supported by two other massive elements - a vase, which serves as the base of the tree, and a top in the shape of a crescent moon and an eight-pointed star. These large elements, presented in the shape of massive gold medallions, are complemented with smaller elements - leaves, "stamens", shoots, and stalks. The motifs can be traced to other applied arts, both Crimean-Tatar and Ottoman-Turkish. For instance, the four tree leaves resemble the paisley design in their adaptation, which is popular in Indian and Iranian textiles, and Turkish embroidery. The eight-pointed star in a crescent moon was a popular motif in the $16^{\text {th }}-19^{\text {th }}$ century Ottoman art, it was widely used in the items, which belonged to those in positions of power and authority [Sattarova]. The motif was introduced to Crimean-Tatar embroidery in different forms. On the tobacco pouch from the Sinferopol Museum, the star is in the shape of an eight-petal flower, halfway inside is a thin crescent moon. It should be noted that a halfcrescent with a star in its natural form is only found in the embroidery on the belt from the NM RT (Belt No.1). However, after closer inspection of the upper rows of Belt No. 2 and the belt from the Simferopol Museum, one can postulate that this central element emerges as a variation on the "ayyulduz" (crescent-and-star) motif: the crescent and star merge to become a flower with sharpened petals.
In the middle section of the composition, the "tree of life" is flanked by two tall jugs with long necks, rounded bodies, and curved pouring lips. Such jugs are common and characteristic items in Crimean Tatar households, seen also on other belt decorations.

Both belts are made using a light silk-like fabric similar to the Turkish muslin, as for the strands and the weaving, they are similar in quality to marquisette and gauze. This simple linen cloth was used for many items in Turkish and Crimean Tatar embroidery tradition; the popularity of this textile in the latter culture is explained by the prevalence of special embroidery techniques.

The decorations of the wedding belts came to reflect the tradition of combining coloured silk and cotton embroidery with gold and silver threads, the tradition finding its way to a wide array of Crimean Tatar items.

The examples are: a marama scarf, made of light cotton fabric with double-sided coloured embroidery floss satin stitch and some details in metallic strands, and an abtez towel, made of a denser fabric. In accordance with this tradition, the embroidered belts from Kazan have smaller details, such as vines, buds, and small leaves - done in satin stitch technique, complementing the main ornament and enlivening it.

The thread, used to make all the main details on the Kazan belt embroideries, deserves our special attention. It is made of a silk thread with a very thin metallic (silver) foil strand woven onto it. The resulting thread - lightweight, thin, and durable possesses the necessary qualities for double-sided embroidery. The bright golden lustre, which has not faded after a century, suggests a high gold content, which is confirmed by the manifests documenting the shipments of golden threads for Bukhara embroidery: it used a thin metallic thread tightly woven onto a silken one. Relatively highpurity silver alloys were used for the thread, sometimes as high as $84 \%$. To manufacture the "golden" thread, the silver thread was covered with gold. It is worth noting that from the second half of the $19^{\text {th }}$ century Russian merchants act as suppliers of soft spun gold to the vast Russian market, including Central Asia and Crimea, while in an earlier period, threads for gold embroidery were brought to Russia from the East. Goncharova names the factories of Malyutin, "Alekseev and K", the trading houses of V. Vishnyakov and Sh. Shamshin [Goncharova, p. 18]. Interestingly, the colour of the silk thread, used as the base for the gold thread, changed throughout the years, which 
made it possible to date them. P. A. Goncharova states that "in the earlier items from the 1830s to 1870 s, the golden thread was woven onto a yellow silk thread of various shades, dyed to resemble gold. Orange silk thread was used in the eighties. ... Closer to the $1910 \mathrm{~s}$, the quality of gold had declined, and it was woven onto a yellow cotton thread" [Goncharova, p. 19].

The base for the gold thread in Belt No.1 is a straight silk thread of milky yellow colour, while in Belt No. 2 it is twisted orange silk. Belt No.1 is additionally coloured with a natural dark yellow dye to strengthen the appearance of the golden embroidery, with painted contours spilling outside the embroidered areas. In contrast, the embroidery stitches of Belt No. 2 are lightly covered with embroidery, so that the fabric underneath them is seen through.

It is interesting to compare the belt embroidery techniques with those of the Bukhara embroidery, which is mostly done using satin stitches. "The threads used for the satin stitch were coloured yellow, so that they did not stand out in case the golden threads went apart. The threads were dyed using ginger root - "zarchuba" - by the embroiderers themselves. In cases where embroidery was done directly on the fabric, without the satin stitch, the fabric was dyed yellow too. Gold threads were sewn through the fabric only when light materials were used, such as calico, tulle, and gauze. In Bukhara, however, embroidery was done on gauze in the same way as on denser fabrics - using the point couche technique. Only the most experienced embroiderers have reported that they remember gauze being embroidered with golden threads on the fabric. This can be approximately dated to the end of the first and the beginning of the second quarter of the $19^{\text {th }}$ century, when this method was used to make male head garments - turbans (chalma). The embroiderers believe that this was done using the chain stitch. The items themselves have not survived to this day" [Goncharova, p. 24]. Two details, mentioned here by P. A. Goncharova, are important when looking into the embroideries of the NMRT collection. The first is the dying of the fabric under the golden embroidery, which is found in Belt No.1. The second is the accounts of the informants on the age of the double-sided gauze golden embroidery. It shows that those items, preserved in the Crimean Tatars' embroidery techniques, are indubitably ancient. The items prove the existence of the mentioned techniques, as well as help trace their origins and development.
Expert P. Chepurina recognises 10 types within the Crimean Tatar embroidery [Chepurina, p. 3-6]. The decorations of the belts studied here use one of the main types of double-sided decorative embroidery - the double-sided satin stitch with no lining, known as "Tatar ishleme" ("Tatar work/stitch"). "Tatar ishleme" was the most widespread type of ornamental embroidery, with more than 70 variations, and was subdivided into two categories simple and counted. The first category is the simple satin stitch. As compared to the second category, the count of the stitches did not matter in this case, and there was no scheme for the reverse stitch in the ornament. Both items from the NMRT have ornaments using the simple satin stitch: the edges of the ornamental motifs, "circles", "droplets", and other small elements. The second category of the "Tatar ishleme" are counted variants, which were the main types used in creating the patterns. They are prevalent when large areas are to be covered, such as rosettes, leaves, stars, flowers, pitchers, etc. P. Chepurina counted approx. 100 combinations within the two variants of the stitch with specific names "el iyip shashirma" ("do not lose the path") and "tarleme" ("the fencing one"). These are believed to be the main techniques used in the Crimean Khanate. In the belts from the $\mathrm{Ka}$ zan collections, we observe larger details being filled with a net made of geometric shapes (squares, rhombi, triangles, and wide zigzags). They create an effect that adjacent areas, filled with different patterns, have different textures and light reflections.

The mentioned peculiarities are found in other embroidery items from the museum's collection, recorded in the acquisitions act of 16 October, 1936. The document states that the items were bought from "Kasimova Zubeyda, living in Crimea, Yalta, Deregoy village, House 7, Flat 1, Tik Str. ... Hand-made by Crimean Tatars in 1860" (Protocol dated 16.10.1936). Along with the gauze belt (Belt No.1), two pouches with gold embroideries, sock straps, and two items recorded as "golden thread embroidery ... similar to a carpet" were bought from Zubeyda Kasimova. Both items, with edges with gilded silver threads over an orange thread, are made from two strips of fabric - green silk satin (68 by $42 \mathrm{~cm}, \mathrm{KP}-10660)$ and crimson silk satin (69 by $39.5 \mathrm{~cm}, \mathrm{KP}-10662$ ). This kind of embroidery and reinforcement at the edges was used for the ends of decorative towels, which were made from colourful fabrics and used as furnishing inside the house. An example of this type of a towel, made from crimson silk with similar embroi- 
dery at the edges and fringes, is found at the Bakhchysaray Museum [Akchurina-Muftieva, Table $3.7 \mathrm{e}]$. The fabric seems to have deteriorated with time, and its edges were used to make other decorative items - tablecloths and pillowcases. In the tablecloths from the Kazan collections, all decorations with vines and large eight-petal rosettes have rather large features. The ornament is trying to cover the whole space, while the resulting small gaps are filled with whisks, curling vines, and small disks.

The same traits are present in the two table pouch embroideries. The pouch is made of two rectangular pieces of velvet cloth of deep colours crimson (KP-10661) and violet (KP-10665). The decorations on the pouches are again dominated by large elements - stars, rosettes, vases, leaves, heart-like figures, and flowers. The pouches are decorated on both sides; the ornaments share the same basis, yet one side lacks smaller details. The traits of this style, monumental and laconic, are comparable to the embroidery on the pouch from the Russian Museum of Ethnography, in which the tree of life motif is broken up, and the composition is divided into tears [Traditsionnaia, il. p. 95].

The density of the ornament and large size elements are also found among smaller items of the collection - the "chorab-bau" straps, worn by the groom on a wedding day to support high socks under the knees. Those were made of strips of velvet, padded with cardboard, having ribbons and tassels at its edges. [Roslavtseva, p. 53].

Short inscriptions with Islamic religious formulas are a common addition to the Crimean embroidery decorations. On Belt No. 2 and the green satin tablecloth (KP-10660) those are "mashallah" and "subhanallah", written in Arabic script (but not calligraphically) with a gold thread. Mashallah (Mashaallah, [ماشثاءالله], translates from Arabic as "Allah's will" [Maxmutov, Xamzin, Sajfullin, p. 255]). It is used to express a pleasant surprise, joy, and approval, and is common in evil eye warding amulets. Subhanallah (Subhanallah, [سبحان الله]], translated as "praised be Allah") - is a form of praise used at the moments of surprise [Maxmutov, Xamzin, Saifullin, p. 531]. In informal language, folklore (sayings, proverbs) and folk literature, both phrases are often used together, empowering each other; they are often used in applied arts. In Crimean Tatar embroideries, the phrases are found on prayer mats, children's black cloth caps, worn to ward off evil eye, and belts. Other religious phrases and words of praise were sewn on various items, which are all found in a wedding attire.
Embroidered onto the lower edges of Belt No. 1 ends is a well-wishing writing, made of coloured (dark-brown) silk. Unfortunately, only parts of the Crimean Tatar inscription with Islamic religious phrases is readable ${ }^{1}$.

The gold embroidery artifacts from the National Museum of Republic of Tatarstan are remarkable pieces of Crimean Tatar art dated from the second half of the $19^{\text {th }}$ century. They provide rich material, in terms of a technical and ornamental repertoire, for a comparative study of folk embroidery of the Crimean and Kazan Tatars ${ }^{2}$.

\section{Illustrations:}

1. Male bridal belt. Gold thread embroidery on silk. (KP-10664)

2. Male bridal belt. Gold thread embroidery on silk. (KP-24238)

3. Towel. Satin, gold thread embroidery. (KP10660)

4. Towel. Satin, gold thread embroidery. (KP10662)

5. Bridal tobacco pouch. Gold and silk thread embroidery on velvet. KP-10665

6. Bridal tobacco pouch. КП-10665. Reverse side.

7. Bridal tobacco pouch. Gold and silk thread embroidery on velvet. KP-10661

8. "Chorab-bau" straps. Gold and silk thread embroidery on velvet, sequins, spun gold, lace. KP10663/1-2.

\section{References}

Akchurina-Muftieva, N. M. (2008). Dekorativnoprikladnoe iskusstvo kry'mskix tatar. [Decorative and Applied Arts of the Crimean Tatars]. 392 p. Simferopol'. (In Russian)

Chepurina, P. Ya. (1938). Ornamental'noe shitee Kry`ma. [Ornamental Embroidery of Crimea]. MoscowLeningrad, 64 p. (In Russian)

Goncharova, P. A. (1986). Zolotoshveinoe iskusstvo Bukhary` [Gold Embroidery Art of Bukhara]. 110 p. Tashkent. (In Russian)

Gulova, F. F. (1980). Tatarskaia narodnaia vy`shivka. [Tatar Folk Embroidery]. 78 p. Kazan`. (In Russian)

Iskusstvo islama (2001) [The Art of Islam]. Katalog vy`stavki. 88 p. St. Petersburg. (In Russian)

Makhmutov, M. I., Khamzin, K. Z., Saifullin, G. Sh. (1993). Arabsko-tatarsko-russkij slovar zaimstvovanij (Arabizmy`i farsizmy`v yazy`ke tatarskoj literatury'). [Arabic-Tatar-Russian Dictionary of Borrowings (Arabisms and Farsisms in the Language of Tatar Literature)]. Kazan`. (In Russian)

\footnotetext{
${ }^{1}$ In reading inscriptions on belts, the author used the kind consultations of N. G. Garaeva and Z. S. Minnullin.

${ }^{2}$ Translated by S. Sattarov.
} 
Krymskotatarskoe dekorativno-prikladnoe iskusstvo 19-20 vv. (2001) [Decorative and Applied Art of the Crimean Tatars]. Al'bom. Sostavitel' Fatime Asanova, redaktor Ismet Zaatov. Simferopol. (In Russian)

Roslavtseva, L. I. (2000). Odezhda kry`mskikh tatar kontsa XVIII - nachala XIX v. Istoriko$e^{`}$ tnograficheskoe issledovanie [Clothing of the Crimean Tatars of the Late $18^{\text {th }}-$ Early $19^{\text {th }}$ Century. Historical and Ethnographic Research]. 104 p. Moscow. (In Russian)

Sattarova, L. I. (2010). K atributsii osmanskoi vy`shivki iz sobraniia Gosudarstvennogo muzeia izobrazitel`ny`kh iskusstv Respubliki Tatarstan [On the Attribution of Ottoman Embroidery from the Collection of the State Museum of Fine Arts of the Republic of Tatarstan]. Nasledie islama $v$ muzeiakh Rossii: izuchenie, atributsiia, interpretatsiia. Materialy` nauch.prakticheskoi konferentsii. 3-4 dekabria 2009 goda. Kazan`, pp. 164-173. (In Russian)
Sokrovishha Osmanskih sultanov. Iz sobraniia Muzeia dvortsza Topkapy', Stambul (2010) [Treasures of the Ottoman Sultans. From the Collection of the Topkapi Palace Museum, Istanbul]. 200 p. Moscow. (In Russian)

Spasskaia, E. Yu. (1926). Staro-Kry`mskie uzory`. [Old Crimean Patterns]. Izvestiia obshhestva obsledovaniia i izucheniia Azerbajdzhana. Baku, No. 3, pp. 181-184. (In Russian)

Traditsionnaia kultura tatar XIX-XX vekov. Katalog vy`stavki (2012) [Traditional Culture of the Tatars of the $19^{\text {th }}-20^{\text {th }}$ Centuries. An Exhibition Catalogue]. 168 p. St. Petersburg. (In Russian)

Valeeva-Suleimanova, G. F., Shageeva, R. G. (1990). Dekorativno-prikladnoe iskusstvo kazanskikh tatar. [Decorative and Applied Arts of the Kazan Tatars]. 216 p. Moscow. (In Russian)

\title{
О ГРУППЕ КРЫМСКО-ТАТАРСКИХ ВЫШИВОК В СОБРАНИИ НАЦИОНАЛЬНОГО МУЗЕЯ РЕСПУБЛИКИ ТАТАРСТАН
}

\author{
Лилия Илевна Саттарова, \\ Национальный музей Республики Татарстан, \\ 420111, Россия, г. Казань, ул. Кремлевская, 2, \\ liliya.sattarova@hotmail.com.
}

\begin{abstract}
В статье впервые описана группа крымско-татарских вышивок, предметы которой поступили в собрание музея в 1936 и 1997 гг. Прослежена история отдельных артефактов и уточнена их атрибуция, а также выявлено изменение назначения вещей в связи со сменой среды бытования. Традиция золотошвейного искусства крымских татар показана в комплексе его техникостилистических характеристик - основных мотивов и наиболее распространенных композиционных схем, техник вышивания, используемых традиционных материалов основы и специальных вышивальных нитей. Привлечен широкий ряд аналогий из собраний музеев России. Большинство предметов коллекции публикуется впервые.
\end{abstract}

Ключевые слова: крымские татары, золотая вышивка, техники вышивки, Национальный музей Республики Татарстан, коллекции.

Золотошвейное искусство татарских мастериц, ставшее широко известным благодаря массовому производству национальных головных уборов в рамках ичижно-каляпушного промысла, развивавшегося в Казани во второй половине XIX - начале XX века, представлено в наших музейных собраниях. Декор традиционных женских головных уборов калфак, мужских тюбэтэй и каляпуш, бархатных женских туфель позволяет судить об устоявшемся наборе орнаментов, материалах и технических приемах вышивки, наиболее распространенных способах их сочетания. Вышивка изделий, входивших в ассортимент промысла, производилась по бархату темных тонов - синему, зеле- ному, бордовому, коричневому - металлическими нитями специального качества, используемыми для создания на поверхности объемных стежков способом вприкреп. Укладка стежков производилась по картонной основе, часто с использованием ватной подложки. Различный порядок стежков (гладь, елочка, шахматный порядок), а также их разная плотность и высота, дополнение вышивки металлическими блестками обеспечивали вариативность создаваемой декоративной поверхности.

Представления о репертуаре татарского золотошвейного искусства дополняют «казанские полотенца», которые вышивались тамбурным 
швом по белому полотну, дополнялись золотым позументом и бахромой.

Таким образом, набор декорированных золотой вышивкой изделий казанских татар довольно ограничен [Гулова]. Золотая вышивка практически не встречается в традиционной одежде; ввиду прервавшейся традиции не производились с использованием данной техники изделия религиозного назначения, предметы украшения светского или культового интерьера. В этом контексте исследование ряда артефактов, традиционно относимых к коллекциям татарских тканей и вышивок, представляется интересным и может принести неожиданные результаты. Так, новые подходы к атрибуции покрывала «Китап» из собрания Государственного музея изобразительных искусств Республики Татарстан позволили выдвинуть аргументы в пользу его принадлежности к кругу османско-турецких вышивок второй половины XIX века [Саттарова].

В этнографической коллекции Национального музея Республики Татарстан (далее - HM РТ) выделяется группа вышивок, по своим технико-стилистическим характеристикам отличающихся от известных нам образцов казанских вышивок золотом. Вещи этой группы различаются по материалу основы (две вышивки выполнены на кисее, четыре - на бархате, две на сатине), а также по назначению - мужские пояса и подвязки на чулки, кисеты и чехлы на подушки. Рассмотрим эти предметы подробнее.

Два образца из белой ткани, близкие по характеру декора, материалам и технике, украшены дважды повторяющейся композицией с условно трактованным вазоном, ветвями, листьями и плодами. В литературе сложилась традиция считать эти артефакты футлярами для книги (для Корана) и относить их к XVIII-XIX вв., указывая в качестве места бытования Казанскую губернию [Валеева-Сулейманова, Шагеева, c. 166]; с учетом этой атрибуции данные памятники экспонировались на выставках «Искусство ислама» (2001, Казань), «Сокровища музея тысячелетию Казани» (2005, Казань), «Декоративно-прикладное искусство казанских татар: история и современность» (2009, Казань, 2010, Ульяновск).

Как в композиции, так и в техническом отношении эти вышивки имеют множество аналогий, которые встречаются в коллекциях Республиканского крымско-татарского музея искусств (Симферополь) [Крымскотатарское.., ил. 58-60, 65, 69], Государственного музея Востока
(Москва), Российского Этнографического музея (Санкт-Петербург) и других собраний. Исследования по этнографии и декоративноприкладному искусству крымских татар четко определяют назначение этих вещей как свадебный пояс жениха. Он являлся частью преподносимого во время сватовства подарка невесты жениху, который состоял из девяти предметов и поэтому назывался «докуз» («докъузлама»).

Пояса отличались особым разнообразием в комплексе костюма горно-прибрежной группы крымских татар. В их ношении нашли отражение как местные традиции, так и влияние османско-турецкого платья. Влияние османской традиции представляется заметным в подразделении поясов, в использованных для их изготовления материалах. Кушаки, повязываемые поверх платья, а также учкуры, служившие для вздержки шаровар или верхних штанов, имели устойчивые традиции ношения, богато декорировались, могли служить ценным подарком и быть важной деталью церемониальных одеяний. Так, в коллекции Дворца-Музея Топкапы хранится золотошвейный кушак XVII в.: по золотому фону цветными шелковыми нитями выполнен узор расположенных в ряд кипарисов, окруженных ветвями с гиацинтами, между которыми помещены тюльпаны [Сокровища.., с. 161, кат. 82]. Свадебный пояс крымских татар является частью данной традиции; жених не пользовался этим поясом после свадьбы. Видимо, со временем с изменением моды, а также возрастанием покрываемых декором плоскостей пояса, увеличением доли золотой вышивки пояс превратился в обрядовую вещь. По данным Л. И. Рославцевой, свадебный пояс назывался «Кшак», «К концу 19 в. этот пояс стали сшивать на концах и надевали его через голову. Из предмета обихода он превратился в символ супружества» [Рославцева, с. 53].

Материалы и техники вышивки свадебного пояса представляют значительный интерес. Традиционно его шили из тонкого муслина (кисеи), концы вышивали цветными шелковыми и металлическими нитями. Экземпляры из НМ РТ, имея сходство с точки зрения назначения и используемых материалов, композиционных приемов и набора мотивов, различаются в деталях трактовки орнаментальных мотивов и в характере исполнения.

Пояс №1 (КП 10664), сделанный из одного куска ткани шириной 40 см, еще сохранил свободную от вышивки центральную часть. Вышитые концы пояса, согласно традиции, сшиты 
вместе с одной стороны (размеры вышитой части: ширина 79 см, высота 49 см) и продублированы, видимо, в более позднее время, белой хлопчатобумажной тканью.

Второй пояс (КП-24238) приобретен музеем в 1997 г. По информации хранителя М. К. Завьяловой, история вещи связана с приездом в Казань бабушки сдатчицы, крымской татарки, которая вышла здесь замуж. В крымском доме вещь являлась украшением интерьера; в Казани потомки первой владелицы использовали ее в связи с религиозными целями: драгоценной вышивкой накрывали Коран. Видимо, центральная часть пояса разрезана посредине, загнута, затем зашита более плотной хлопковой тканью; размеры вышитой части $65 \times 42$ см.

Основу декора поясов составляет мотив «древа жизни». Рисунок в виде разветвленного дерева, несомненно, имел глубокое символическое значение. В нем содержится благопожелательный смысл, связанный как с земной жизнью, дальнейшим счастливым супружеством и многочисленным потомством, так и представлениями о духовном совершенствовании, связи поколений, передаче знаний и опыта. Буквальной аналогией композиций поясов из НМ РТ можно считать лишь экземпляр из коллекции симферопольского музея [Крымскотатарское.., c. 65]; в других поясах «древо» имеет иной вид: пальмовидное древо на поясах из Государственного музея Востока и симферопольского музея, а также «древо» с основанием в виде вазона и одинаковыми шестилепестковыми цветками в коллекции симферопольского музея.

Композиция вышивки (пояс №1) своей гармонией и продуманностью, уравновешенностью крупных элементов орнамента, плотностью заполнения узором, пожалуй, является лучшим из известных нам образцов. Восьмилепестковая розетка пятикратно повторена в узоpe - в центре и в четырех углах. Мотив розетки с восемью лепестками встречается в декоре свадебных поясов Старо-Крымского района, в частности зарисованных в начале XX в. А. М. Петровой [Спасская, рис. 7 (387)], он является основным мотивом золотой вышивки девичьего шарфа второй половины XIX в. из района Бахчисарая в коллекции ГМВ (ГМВ, № 2798 III) [Рославцева, цветная вклейка, ил. 6].

Вертикальную ось композиции держат еще две массивные детали - монументально трактованный вазон, основа «древа» в нижней его части, и завершение в центре верхнего яруса в виде полумесяца с восьмилучевой звездой. Эти крупные элементы, имеющие вид массивных золотых медальонов, дополнены мотивами более мелкого масштаба - листьями, «тычинками», побегами и вьющимися стеблями. Источники мотивов могут быть найдены в других видах декоративно-прикладного искусства - как крымско-татарского, так и османско-турецкого. Так, четыре стилизованных листа «древа» напоминают в своей трактовке фигуры «восточных огурцов», популярный мотив «бута» индийских и иранских тканей и турецких вышивок. Восьмилучевая звезда в полумесяце - популярный мотив османского декоративного искусства XVI-XIX вв., имеющий яркие примеры в украшении предметов, связанных с представлением власти и государства [Саттарова]. Мотив вошел в словарь крымско-татарского узорного шитья в разных видах. На вышивке кисета из симферопольского музея звезда имеет вид восьмилепесткового цветка, наполовину объятого тонким серпом полумесяца. Следует отметить, что в чистом виде полумесяц со звездой присутствует только в вышивке пояса из Национального музея (Пояс №1). Однако при ближайшем рассмотрении элементов верхнего яруса вышивки пояса № 2, а также золотошвейного пояса из симферопольского музея возникает предположение о том, что центральный элемент возник как стилизация мотива «ай-юлдуз»: полумесяц и звезда срослись, превратившись в цветок с заостренными лепестками.

В среднем ярусе композиции «древо» фланкировано парами высокогорлых кувшинов с округлым туловом и тонким изогнутым носиком. Такие кувшины - характерный предмет бытового обихода крымских татар, они встречаются на вышивках других поясов.

Для изготовления обоих поясов использована легкая шелковая ткань типа турецкой тюльбент (близка по качеству нитей и переплетению к маркизету, кисее). Такая ткань простого полотняного переплетения была основой для изготовления многих изделий в богатом ассортименте турецких и крымско-татарских вышивок; предпочтение этого вида ткани в последних объясняется особой популярностью счетных техник («эсаб ишлеме»).

В декоре свадебных поясов нашла своеобразное отражение традиция сочетания вышивки цветным шелком и хлопком с шитьем золотом и серебром, что проявилось в украшении самых разных по назначению изделий крымских татар. Так, двусторонней гладью цветными мули- 
не с исполнением некоторых деталей металлическими нитями вышивался шарф из легкой хлопчатобумажной ткани - марама, полотенце абтез (из более плотной ткани). Как следование этой традиции, в казанских поясах мелкие детали - побеги, почки, мелкие лепестки - выполнены нитями цветного шелка в технике глади, служа дополнением основного узора и оживляя статичную в целом композицию.

Особенная нить, которой выполнены все основные элементы композиции поясов казанского собрания, заслуживает отдельного рассмотрения. Она представляет собой шелковую нить, на которую плотно спрядена тончайшая полоска металлической (серебряной) фольги. Полученная нить, легкая, тонкая и прочная, обладает необходимыми качествами для исполнения двустороннего шитья. Золотой блеск нити, не утраченный за прошедшее столетие, говорит о высоком содержании золота. Подтверждение данному предположению находим в сведениях о поставках золотых нитей для бухарского шитья, в котором использовалась тонкая металлическая нить, туго спряденная на шелковую. Для ее изготовления использовался сплав серебра более или менее высокой пробы - в лучших сортах до 84 \%. Для получения «золотой» нити серебряная нить покрывалась позолотой. Стоит отметить, что со второй половины XIX в. поставщиками мягкого пряденого золота на обширный российский рынок, в том числе в Среднюю Азию и в Крым, были российские производители, в то время как в более ранний период нити для золотошвейного производства привозились в Россию с Востока. П. А. Гончарова называет фабрики Малютина, «Алексеева и К», торговые дома В. Вишнякова и Ш. Шамшина [Гончарова, с. 18]. Любопытно, что цвет шелковой нити, служившей основой для пряденого золота, был различным в разные периоды, что может служить одним из датирующих факторов. П. А. Гончарова указывает, что «на более ранних изделиях 30-70-х годов XIX века золотая нить спрядена в большинстве случаев на желтую разных оттенков шелковую нить, т. е. окрашенную под цвет золота. В 80-х годах употреблялась оранжевая шелковая нить ... К 10-м годам XX века относится появление золота более низкого качества, спряденного на бумажную желтую нить» [Гончарова, с. 19].

При внимательном изучении поясов из коллекции НМ РТ можно заметить, что в поясе № 1 основа золотой нити - некрученая шелковая нить желтовато-молочного цвета, в поясе № 2 - скрученная шелковая нить оранжевого цвета. В поясе № 1 для усиления эффекта золотой вышивки ткань под орнаментальными фигурами выкрашена в темно-желтый цвет (подкраска каким-то натуральным красителем, контуры окрашенных на ткани фигур выходят за контуры вышивки). Напротив, в поясе № 2 фигуры заполнены орнаментальными швами ажурно, ткань просвечивает сквозь них.

Любопытным представляется сравнение технических особенностей шитья свадебных поясов с материалами и техниками бухарского золотого шитья, которое в основном является шитьем по настилу. «Нитки настила под шитье золотом окрашивались в желтый цвет, чтобы они не бросались в глаза, если золотые нити разойдутся. Окрашивание ниток корнем желтого имбиря - ,зарчуба“" производилось самими вышивальщиками. В тех случаях, когда шитье производилось непосредственно по ткани, без настила, последняя также окрашивалась в желтый цвет. Золотые нитки продергивались сквозь ткань только при употреблении легких материй: миткаля, кисеи, тюля. В бухарском золотом шитье по кисее шили так же, как и по плотным тканям - вприкреп. И только в памяти очень старых вышивальщиков сохранилось воспоминание, что в старину по кисее шили самой золотой нитью сквозь ткань. Сведения эти относятся примерно к концу первой и началу второй четверти XIX века, когда таким способом шили по кисее мужские головные уборы - салля (чалма). Вышивальщики предполагают, что такое шитье выполнялось тамбурным крючком. Сами же изделия этого рода до нас не дошли» [Гончарова, с. 24]. Два обстоятельства, упомянутые здесь П. А. Гончаровой, особенно актуальны для нас в контексте рассмотрения вышивок из НМ РТ. Первое - подкрашивание ткани под вышивкой золотом, которое также наблюдается в поясе № 1. Второе - свидетельства информаторов о древности двустороннего шитья пряденым золотом по кисее. Оно подчеркивает несомненное древнее происхождение данного вида вышивок, сохранившихся в репертуаре крымско-татарского орнаментального шитья, более того, делает их уникальными свидетельствами существования указанных технических приемов, позволяет проследить их происхождение и развитие на протяжении определенного периода времени.

Исследователь крымско-татарских вышивок П. Я. Чепурина подразделяет узорное шитье крымских татар на 10 видов [Чепурина, с. 3-6]. 
В декоре рассматриваемых поясов использован один из основных видов двустороннего орнаментального шитья - глухая двусторонняя гладь без предварительного настила, известная под названием «Татар ишлеме» (тур. Tatar işleme - 'татарская вышивка / выделка'). «Татар ишлеме» был самым распространенным видом орнаментального шитья, имел свыше 70 вариантов и с учетом особенностей шитья разделялся на две категории: простую и счетную. К первой категории относится простая гладь. В отличие от швов второй категории здесь не имел значения счет нитей основы и утка расшиваемой ткани, как и не существовала схема расположения прохождения нити узора в обратном направлении. В обеих вышивках из НМ РТ есть узоры, выполненные простой гладью: это завершения и обрамления орнаментальных мотивов, «кружочки», «капельки» и другие мелкие детали узора. Вторая категория швов «татар ишлеме» - счетные варианты, являющиеся основными в создании узора. Они выявляются при рассмотрении заполнений сравнительно больших плоскостей - розеток, листьев, звезд, цветов, кувшинов и т. п. В двух разновидностях шва, имеющих специфические названия «ел йип шаширма» 'не теряй дорожки' и «таарлеме» 'ограждающий', П. Чепурина насчитывала около 100 комбинаций. Считается, что именно эти техники были распространены в ханский период истории Крыма. «Создавая узор, мастерица здесь прошивала стежками ряд в одном направлении, захватывая на определенном расстоянии нити утка расшиваемой ткани, а при обратном проходе нити смещала стежки так, чтобы на уже расшитом пространстве создавался какой-либо из вариантов узора». В поясах из казанских собраний мы наблюдаем заполнение крупных мотивов орнамента сеткой из различных геометрических фигур (квадраты, ромбы, треугольники, широкие зигзагообразные линии). Создается своеобразный эффект, когда прилегающие друг к другу небольшие плоскости, заполненные плотными стежками, формируют интересную по своей фактуре и играющую светом и тенью поверхность.

Указанные особенности характерны и для других вышивок коллекции, история приобретения которых зафиксирована в музейном акте поступления от 16.10.1936 г. В документе говорится, что вышивки куплены «для музея у Касымовой Зубейды, проживающей по адресу: Крым, Ялта, деревня Дерегой, дом № 7, кв. 1 ул. Тик. ...Ручная работа крымских татар, изго- товленная в 1860 году» (Акт от 16.10.1936 г.). Наряду с поясом из кисеи (№ 1) у 3. Касымовой были куплены два расшитых золотом кисета, подвязки на носки и два предмета, которые в книге поступлений музея записаны «вышивка золотой ниткой ... вроде коврика». Действительно, оба предмета, имеющие отделку в виде обвязки крючком из позолоченных серебряных нитей, спряденных на оранжевую нить, сшиты каждый из двух полос ткани - шелкового атласа зеленого (68x42 см, КП-10660) и малинового (69х39,5 см, КП-10662) цвета. Подобной вышивкой и обвязкой по краю украшались концы декоративных полотенец, которые шились из ярких тканей и предназначались для украшения интерьера. Образец такого полотенца из шелка малинового цвета, концы которого расшиты сходными мотивами и обшиты золотной бахромой, хранится в Бахчисарайском музее [Акчурина-Муфтиева, Табл. 3.7 е]. По-видимому, со временем ткань полотенца ветшала, и его концы, покрытые драгоценной вышивкой, использовались для создания других интерьерных форм - настольных салфеток, чехлов на подушку. В салфетках из казанского собрания все фигуры орнамента с побегами и крупными восьмилепестковыми розетками отличаются массивностью, словно они отлиты в золото шитья. Узор стремится к заполнению всей поверхности, не оставляя свободного пространства, а образующиеся узкие пустоты заполняют тонкие усики, завитки побегов, крошечные диски.

Эти же черты характерны для вышивки двух настольных кисетов. Кисет представляет собой мешок, сшитый из двух прямоугольных кусков ткани (бархата) насыщенных цветов малинового (КП-10661) и фиолетового (КП10665). В узоре кисетов ведущая роль также принадлежит крупным мотивам - звезда, розетка, вазон, лист, сердцеобразная фигура, цветок. Кисеты вышиты с обеих сторон; орнаментальная композиция на обратной стороне имеет ту же основу, однако без мелких деталей. Черты этого стиля, монументального и лаконичного, интересно сравнить с вышивкой кисета из Российского этнографического музея (РЭМ 99324), в котором мотив древа жизни подан более дробно, и композиция распадается на ярусы [Традиционная.., ил. с. 95].

Плотность орнаментального заполнения и массивность мотивов отличает и мелкие предметы коллекции - подвязки «чораб-бау», которые жених надевал на свадьбу, обвязывая длинные носки под коленями [Рославцева, с. 
53]. Они представляют собой полоски бархата, проложенные картоном, к краям которых пришиты тесемки и кисточки.

Краткие надписи с текстом мусульманских религиозных формул являются традиционным дополнением орнаментального декора крымских вышивок. В поясе № 2 и салфетке из зеленого атласа (КП-10660) это мусульманские формулы «машалла» и «субханалла», выполненные арабской графикой (не каллиграфически) золотой нитью. Машалла (Машааллах (араб.), [ماثشاءالله], переводят как «То, что хочет Аллах» [Махмутов, Хамзин, Сайфуллин, с. 255]) - слова, выражающие приятное удивление, восторг и одобрение; часто используются на амулетах от сглаза. Субханалла (Субханаллах (араб.), [سبحان الله], переводится как «Слава Аллаху») - формула восхваления, произносимая при удивлении [Махмутов, Хамзин, Сайфуллин, с. 531]. В разговорной речи, фольклоре (поговорки, пословицы), народной литературе обе формулы часто употребляются вместе, усиливая друг друга; они часто используются в произведениях народного искусства. В крымско-татарских вышивках они встречаются на молитвенных ковриках, детских шапочках из черного сукна, носимых от сглаза, поясах; другие религиозные формулы и восхваления вышивались на предметах различного назначения, также имевших свое место в свадебном обряде.

В поясе № 1 по нижнему краю концов расположена благопожелательная надпись, которая вышита цветным (темно-коричневым) шелком. К сожалению, прочитываются только части слов текста на крымско-татарском языке со вставками мусульманских религиозных формул ${ }^{1}$.

Рассмотренные вышивки из собрания Национального музея Республики Татарстан являются замечательными памятниками крымскотатарского золотошвейного искусства, датируемыми второй половиной XIX века. Они дают богатый материал с точки зрения формирования технического и орнаментального репертуара для сравнительного изучения народной вышивки крымских и казанских татар.

\section{Список иллюстраций:}

1. Мужской пояс. Кисея, золотные нити, шелк. (КП-10664)

\footnotetext{
${ }^{1}$ В чтении надписей на поясах автор пользовалась любезными консультациями Н. Г. Гараевой и 3. С. Миннуллина.
}

2. Мужской пояс. Кисея, золотные нити, шелк. (КП-24238)

3. Салфетка. Атлас, золотное шитье. (КП-10660)

4. Салфетка. Атлас, золотное шитье. (КП-10662)

5. Свадебный кисет. Бархат, золотные и шелковые нити, бахрома. КП-10665

6. Свадебный кисет. КП-10665. Обратная сторона.

7. Кисет. Бархат, золотные и шелковые нити, бахрома. КП-10661

8. Подвязки «чораб-бау». Бархат, золотные и шелковые нити, блестки, канитель, тесьма. КП10663/1-2.

\section{Литература}

Акчурина-Муфтиева H. M. Декоративноприкладное искусство крымских татар. Симферополь, 2008. 392 с.

Валеева-Сулейманова Г. Ф., Шагеева Р. Г. Декоративно-прикладное искусство казанских татар. Альбом. М., 1990. 216 с.

Гончарова П. А. Золотошвейное искусство Бухары. Ташкент, 1986.110 с.

Гулова Ф. Ф. Татарская народная вышивка. Казань, $1980.78 \mathrm{c}$. $88 \mathrm{c}$.

Искусство ислама. Каталог выставки. СПб., 2001.

Крымскотатарское декоративно-прикладное искусство 19-20 вв. Альбом. Составитель Фатиме Асанова, редактор Исмет Заатов. Симферополь, 2001.

Махмутов М. И., Хамзин К. 3., Сайфуллин Г. Ш. Арабско-татарско-русский словарь заимствований (Арабизмы и фарсизмы в языке татарской литературы). Т. 1. Казань, 1993.

Рославцева Л. И. Одежда крымских татар конца XVIII - начала XIX в. Историко-этнографическое исследование. М., 2000. 104 с.

Саттарова Л. И. К атрибуции османской вышивки из собрания Государственного музея изобразительных искусств Республики Татарстан // Наследие ислама в музеях России: изучение, атрибуция, интерпретация. Материалы науч.-практической конференции. 3-4 декабря 2009 года. Казань, 2010. C. 164-173.

Сокровища Османских султанов. Из собрания Музея дворца Топкапы, Стамбул. М., 2010. 200 с.

Спасская Е. Ю. Старо-Крымские узоры // Известия общества обследования и изучения Азербайджана. Баку, 1926. № 3. С. 181-184.

Традиционная культура татар XIX-XX веков. Каталог выставки. СПб., 2012. 168 с.

Чепурина П. Я. Орнаментальное шитье Крыма. М.-Л., 1938. 64 c. 


\title{
ТАТАРСТАН РЕСПУБЛИКАСЫ МИЛЛИ МУЗЕЕНЫН ТУПЛАНМАСЫНДАГЫ КЫРЫМ ТАТАРЛАРЫНЫН БИЗӘКЛӘР ТӨРКЕМЕ ХАКЫНДА
}

\author{
Лилия Ил кызы Саттарова, \\ Татарстан республикасы Милли музее \\ 420111, Россия,Казан ш., Кремль ур, 2 нче йорт, \\ liliya.sattarova@hotmail.com.
}

\begin{abstract}
Мәкаләдә кырым татарларының - предметлары музей тупланмасына 1936 hәм 1997 елларда кергән бизәкләр төркеме беренче тапкыр тасвирлана. Аерым артефактларның тарихы күзәтелә hәм атрибуцияләре ачыклана, шулай ук көнкүреш шартлары алмашынуга нисбәтле, әйберләрнең вазифасы үзгәреше дә тәгаенләнә. Кырым татарларының алтын бизәк сәнгате традицияләре аның техник-стилистик сыйфатлары комплексында күрсәтелә: төп мотивлар һәм аеруча киң таралаган композицияон схемалар, чигү техникасы, кулланылган традицион материалларның нигезләре һәм махсус чигү жепләре. Россия музейлары жыелмаларыннан бай аналогияләр китерелә. Коллекциянең күпчелек предметлары беренче тапкыр нәшер ителә.
\end{abstract}

Төп төшенчәләр: Кырым татарлары, алтын бизәк, чигү техникасы, Татарстан республикасының Милли музее, коллекция. 


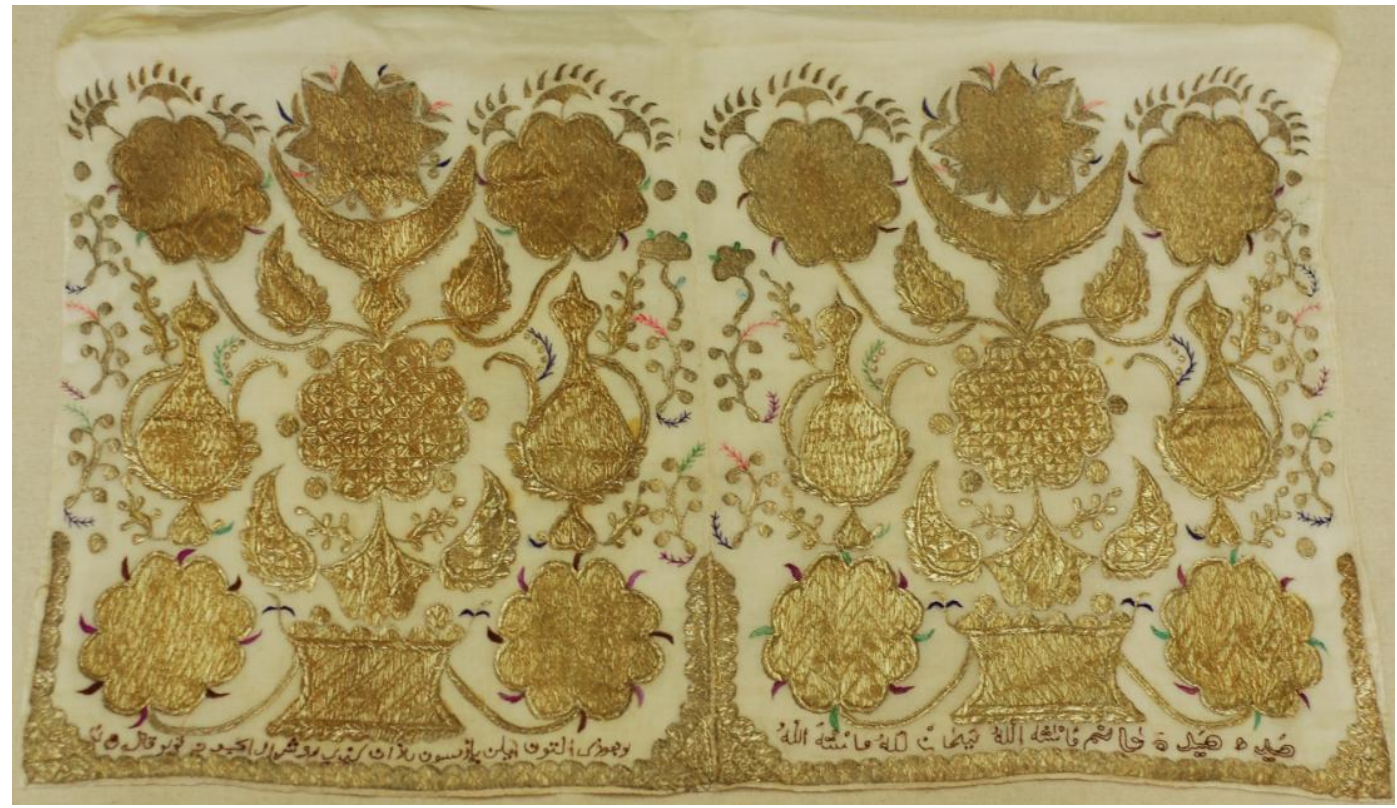

Рисунок 1. Мужской пояс. Кисея, золотные нити, шелк. (КП-10664) 1 рәсем. Ирләр билбавы. Кисея, алтын жепләр, ефәк. (КП-10664)

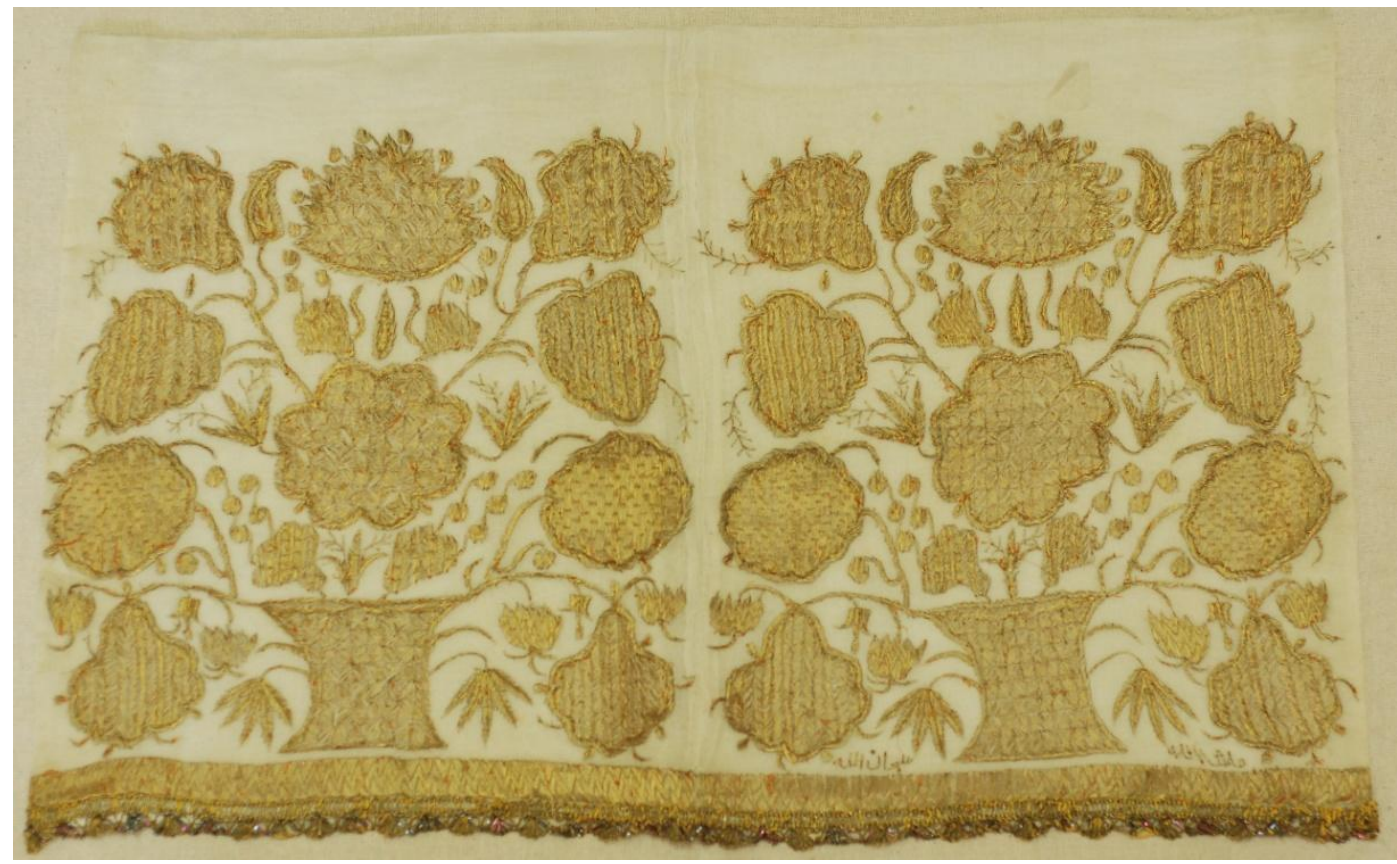

Рисунок 2. Мужской пояс. Кисея, золотные нити, шелк. (КП-24238)

2 рәсем. Ирләр билбавы. Кисея, алтын жепләр, ефәк. (КП-24238) 


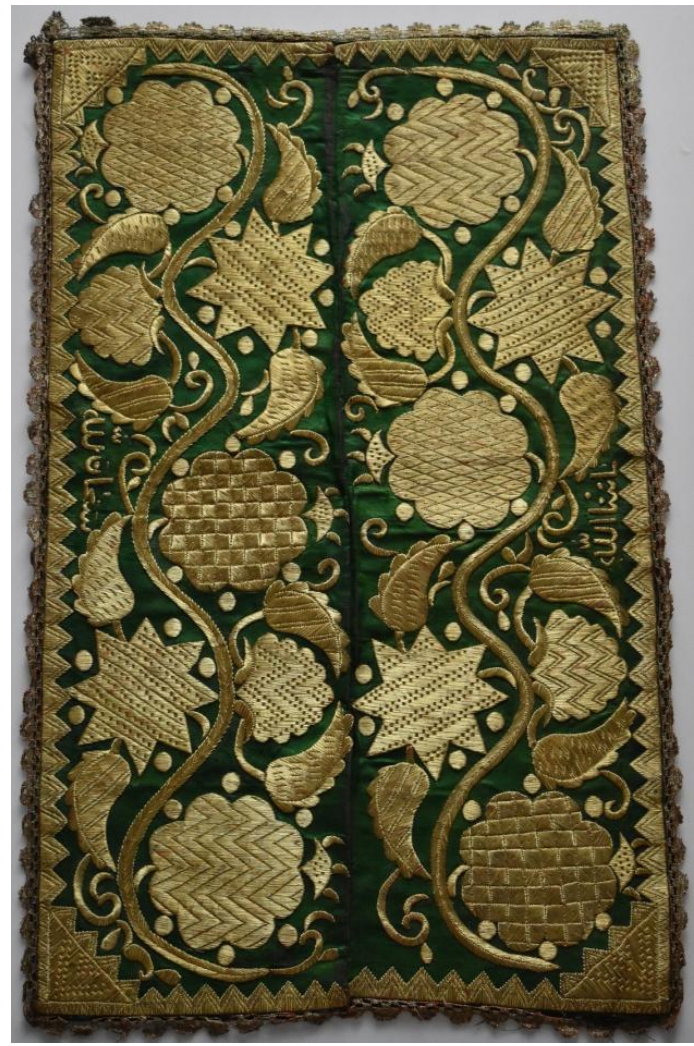

Рисунок 3. Салфетка. Атлас, золотное шитье. (КП10660)

3 рәсем. Салфетка. Атлас, алтын чигү (КП-10660)

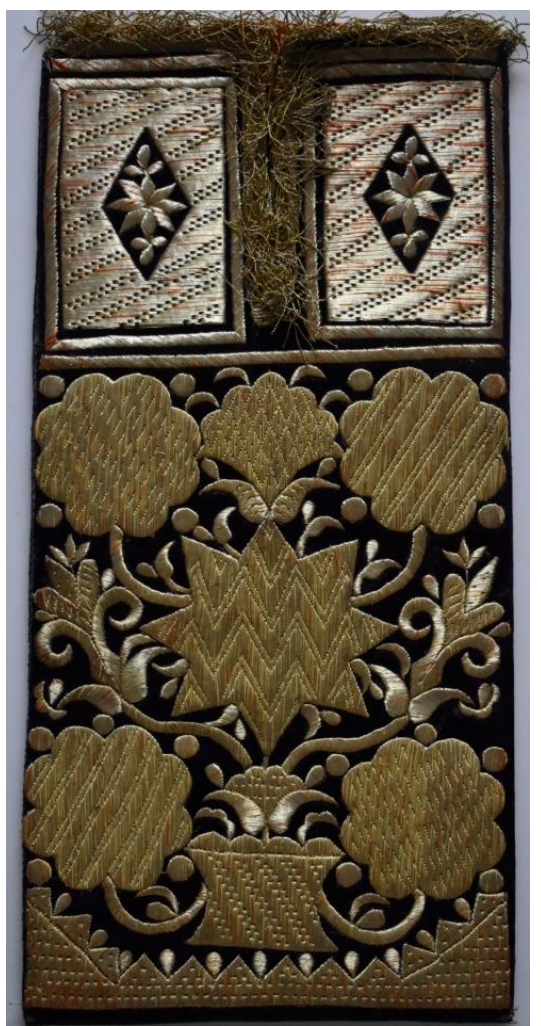

Рисунок 5. Свадебный кисет. Бархат, золотные и шелковые нити, бахрома. (КП-10665)

5 рәсем. Туй янчыгы. Бәрхет, алтын һәм ефәк жепләр, чуклар (КР-10665)

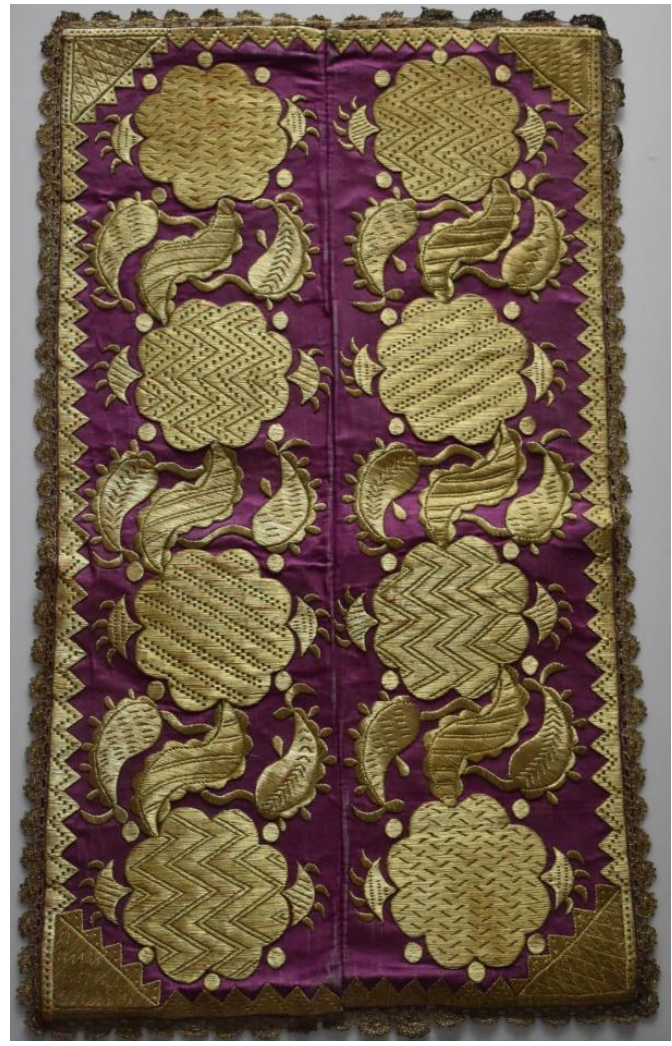

Рисунок 4. Салфетка. Атлас, золотное шитье. (КП10662)

4 рәсем Салфетка. Атлас, алтын чигү (КП-10662)

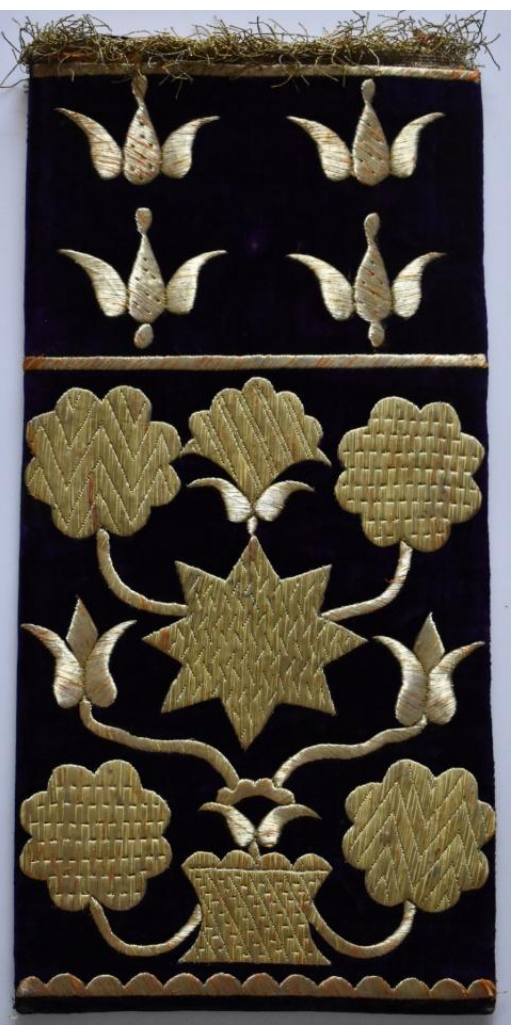

Рисунок 6. Свадебный кисет. (КП-10665). Обратная сторона

6 рәсем.Туй янчыгы. (КП-10665). Икенче ягы 


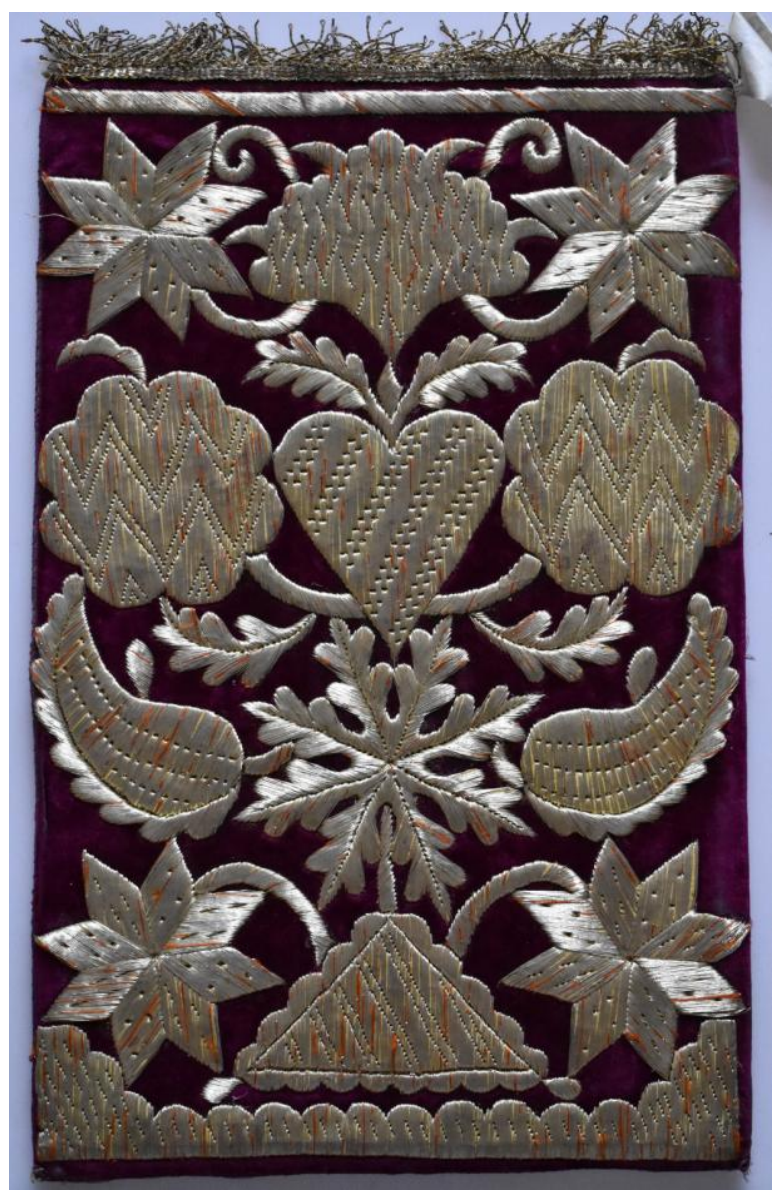

Рисунок 7. Кисет. Бархат, золотные и шелковые нити, бахрома. (КП-10661) 7 рәсем. Туй янчыгы. Бәрхет, алтын һәм ефәк жепләр, чуклар.(КП-1-661)

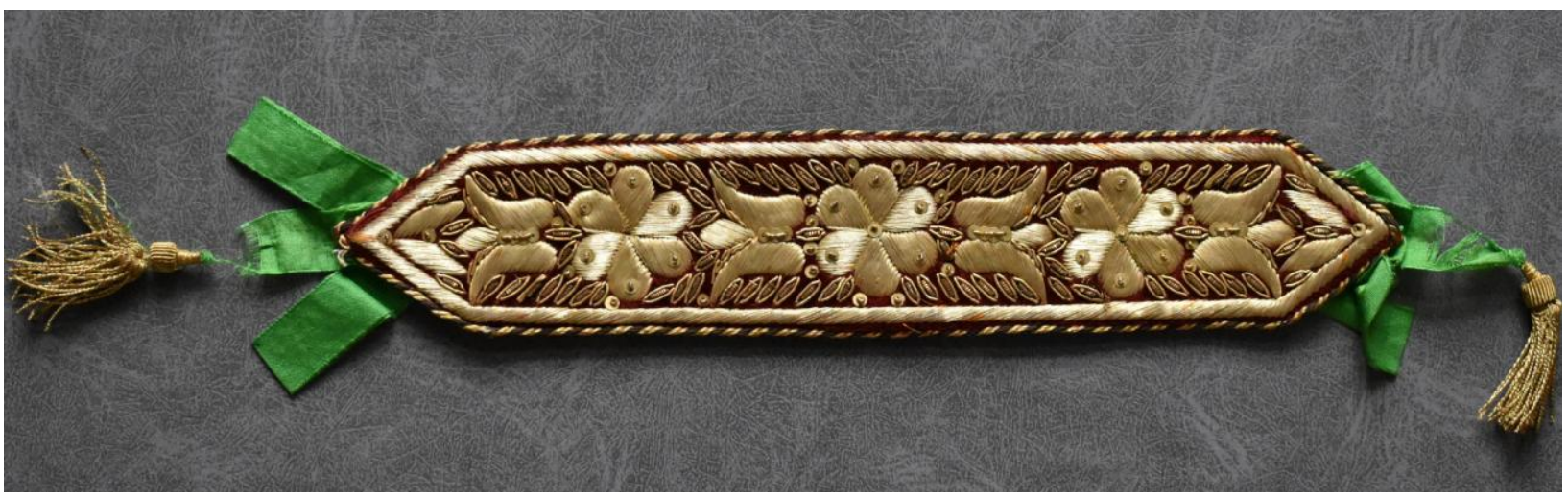

Рисунок 8. Подвязки «чораб-бау». Бархат, золотные и шелковые нити, блестки, канитель, тесьма. (КП10663/1-2)

8 рәсем. «Чораб-бау» бәйләвече. Бәрхет, алтын һәм ефәк жепләр, ялтыравыклар, ука, тасма. (КП-10663/1-2.) 